International Journal of Theoretical and Applied Mechanics.

ISSN 0973-6085 Volume 12, Number 3 (2017) pp. 375-388

(C) Research India Publications

https://dx.doi.org/10.37622/IJTAM/12.3.2017.375-388

\title{
Effect of Tooling Parameters on Bending Force in Air Bending of CR4 steel
}

\author{
Tilak Raj Gupta* \\ Ph. D. Scholar, Department of Mechanical Engineering, \\ I.K.G. Punjab Technical University, \\ Kapurthala $(\mathrm{Pb}), 144603$, India. \\ H.S Payal \\ Professor, Department of Mechanical Engineering, \\ St Soldier Institute of Engineering and Technology (PTU), \\ Jalandhar $(P b), 144001$ India.
}

\begin{abstract}
This study attempts to investigate the effect of process variables like the geometry of die and punch, the orientation of sheet metal and punch speed on bending force in air bending of CR4 steel, by varying one parameter at a time approach. Experiments were conducted using different combinations of sheet orientations, punch velocity, punch radius, die width, and die radius keeping sheet metal blank size constant. Universal Testing Machine was used at different speeds. Effect of parameters that is bending force has been analyzed graphically. The increase of bending force was observed due to an increase of punch radius, and punch speed. Whereas bending force was decreasing due to an increase of die width, and die radius. By changing the orientation of steel sheet from longitudinal to transverse, bending force was increasing. It was observed that the bending force follows polynomial equation of 2 nd order by curve fitting method. The results will be useful as a guideline for tool design engineers and press shop engineers in the sheet metal forming industry
\end{abstract}

Keywords: Air bending; bending force; CR4 steel; die and punch geometry; punch speed; steel sheet orientation

\section{INTRODUCTION}

Bending process is commonly used in fabrication industry making use of the theory of plasticity. In this process, the sheet metal is shaped by straining the metal around a straight axis. During this operation, internal side is compressed and external side is

*Corresponding Author: Tilak Raj Gupta. Email:trg2in@yahoo.com 
stretched as illustrated in Figure 1. This process is of three types, V-die bending, air bending and wipe die bending. The present study is about air bending, known as free bending also. It is a flexible bending process, where, by changing the punch travel various bend angles are achieved using the same tooling. In this process, the sheet metal blank comes in contact with two outside edges of the die and punch nose. It is not supported at bottom and form is made by punch radius and die's opening as illustrated in Figure 2 (a). Air bending is more flexible than its counterpart V- die bending. Different bend angles are achieved by changing the punch and die in $\mathrm{V}$ - die bending process Figure 2 (b). As the punch travel decides the bend angles in air bending, the tool changes required to achieve different angles are reduced. Therefore, use of air bending in automotive and other metal forming industries is very frequent [1-3]. Air bending is suitable for prototype development, part production and small batch production due to flexibility, lesser numbers of changes and low cost of tooling. Air bending is falsely judged as an easily understandable process. Bending behavior of metal sheet in air bending process is complex for sheet material, tool and process [4]. In the recent years, air bending has received the research interest as the process has been recognized as complex one [5].

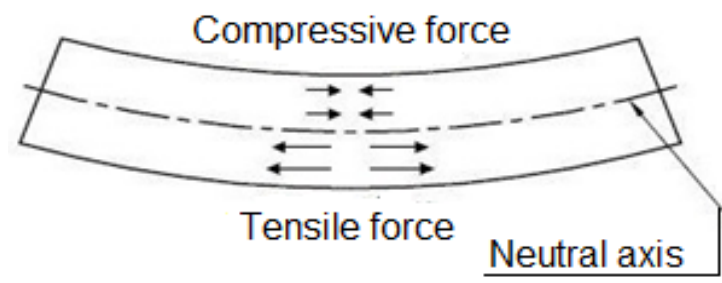

Figure 1. Theory of Plasticity

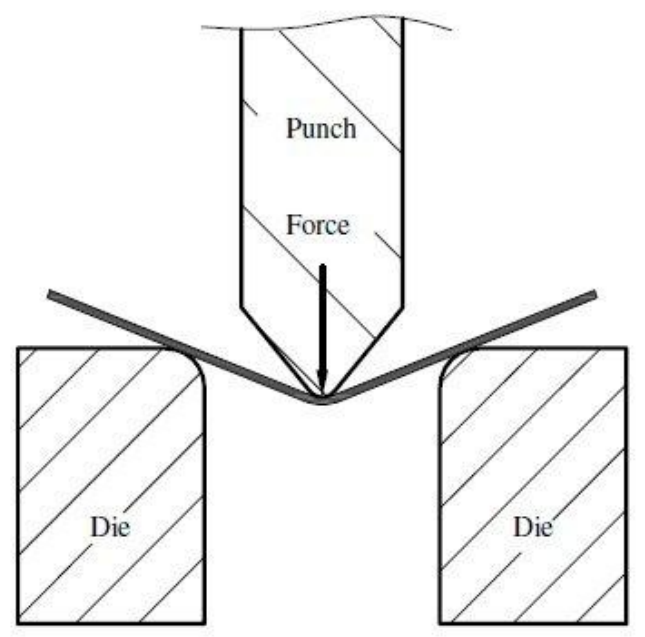

(a)

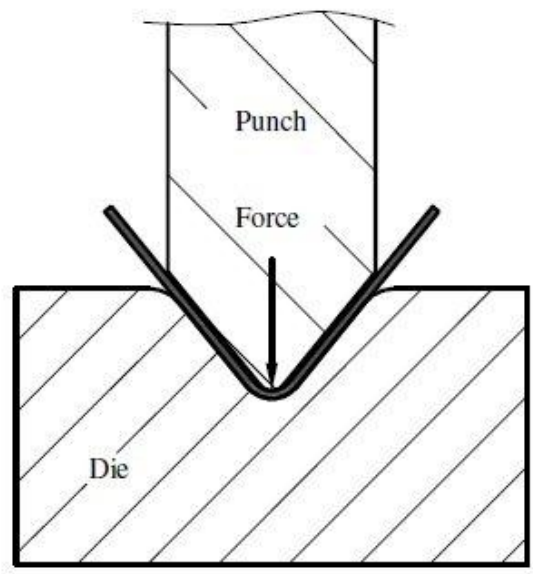

(b)

Figure 2. (a) Air bending (b) V- die bending 
Bending force depends on the punch travel. It starts from zero to maximum and may decrease near the completion of the bend; then it increases abruptly as the punch bottoms down in die bending refer Figure 2 (b). In the case of air bending, once the force starts decreasing, it does not increase again [6] refer Figure 2 (a). Bending force Fmax can be estimated by the equation (1), [6].

$$
\text { Fmax }=\mathrm{K}\left\{(\mathrm{UTS}) \mathrm{Ls}(\mathrm{Ts})^{2}\right\} / \mathrm{Wd}
$$

In this equation, $\mathrm{K}$ includes various factors including friction; UTS is the ultimate tensile strength; Ls is bend length; Ts is sheet thickness \& Wd is die width. Bending force for air bending can be calculated by equation (2). [7]

$$
\mathrm{F}=\left\{4 \mathrm{M} \cos ^{2}(\theta / 2)\right\} /\{(\mathrm{Wd}+2 \mathrm{Rd})-2(\mathrm{Rd}+\mathrm{Rp}+\mathrm{Ts}) \sin (\theta / 2)\}
$$

In this equation, $\mathrm{M}$ is bending moment, $\mathrm{Wd}$ is the die opening, $\mathrm{Rd}$ is the die radius, $\mathrm{Rp}$ is punch radius, Ts is sheet thickness and $\theta$ is the bend angle. So, bending moment, which depends on parameters like material properties and the die geometry etc., is directly affecting the bending force. An analytical approach cannot correctly estimate bending moment during air bending [8-10]. Thus, tool designers use the easy equation (1). In this equation, as already mentioned, $\mathrm{K}$ is not constant rather a factor which varies, so experimental study needs to be carried out further.

Huang, Y. et al. worked on the V- die bending process for studying the effects of variable process parameters and observed that on the increase of die radius, punch load for bending reduces in the initial position and increases in the final position of the bending of steel sheets [11]. Naraynasamy et al. predicted bending force in air bending of interstitial free steel sheets using response surface methodology for his study [3]. Balaji, S.V. et al. conducted experiments with $8 \mathrm{~mm}$ thick plate for 3 different punch radii, using single die setup, and inferred that the load increases to bend the workpiece as the punch radius increases [12]. Srinivasan, R.et al. studied air bending process for bending force behavior of electro galvanized steel sheets [13]. Chatti, S. et al. studied the air bending process by super positioning the incremental stress and observed that bending force and energy requirement both got considerably lowered [14]. Khalatbari, $\mathrm{H}$. et al. studied the incremental forming process to relate formability and time efficiency in high-speed incremental forming [15]. Gupta, Tilak Raj et al. investigated bending and spring back of electro galvanised steel and presented the effect of punch velocity and bend angle [16]. Khadra, F. A. et al. used the kriging approach for forecasting spring back behavior in air bending [17]. Salahshoor, M. analyzed the effects of tool and process parameters in hydroforming process and observed the process path has a great effect on formability [18].

Anisotropy of steel sheet is an important factor influencing its formability. Cold rolling, a thermo-mechanical process, of steel sheets results in anisotropy. The transverse ductility is thus reduced [6]. 
CR4 steel is an aluminum killed steel and has uniform grain structure making it useful for intricate deep-drawing with a non-aging quality. It is manufactured as per IS 513: 2008 [19] in India. Table 1 shows chemical composition \& Table 2 shows mechanical properties at room temperature as per IS 513: 2008 [15]. This grade of steel is free from stretcher-strain, even after prolonged storage. It is used in automotive body parts like back door inner, reinforcement sub-assembly for hinge pillar. Electrical machinery parts, due to its easy spot weldability and formability with high strength. It is friendly with painting and decorative coating. Suresh, K. et al. studied incremental forming and observed a grain refinement in similar steel, after the process [20].

Table 1. Chemical composition of CR4 steel as per IS 513:2008

\begin{tabular}{|c|c|c|c|c|c|}
\hline \multicolumn{2}{|c|}{ Quality } & \multicolumn{3}{c|}{ Constituent, Percent, Max } \\
\hline Designation & Name & Carbon & Manganese & Sulphur & Phosphorus \\
\hline CR4 & $\begin{array}{c}\text { Extra deep drawing } \\
\text { Aluminium killed } \\
\text { (Non-aging) }\end{array}$ & 0.08 & 0.40 & 0.030 & 0.020 \\
\hline
\end{tabular}

Table 2. Mechanical properties at room temperature of CR4 steel as per IS513:2008

\begin{tabular}{|c|c|c|c|c|c|}
\hline \multicolumn{2}{|c|}{ Quality } & $\begin{array}{c}\text { Yield } \\
\text { Stress } \\
\text { MPa }\end{array}$ & $\begin{array}{c}\text { Tensile } \\
\text { Strength } \\
\text { MPa }\end{array}$ & $\begin{array}{c}\text { Elongation } \\
\text { Percent Min }\end{array}$ & $\begin{array}{c}\text { Hardness } \\
\text { Max }\end{array}$ \\
\hline Designation & Name & Max & Max & Lo=50 & HR30T \\
\hline CR4 & $\begin{array}{c}\text { Extra deep drawing } \\
\text { Aluminium killed } \\
\text { (Non-aging) }\end{array}$ & 210 & 350 & 37 & 50 \\
\hline \multicolumn{6}{|c|}{$\begin{array}{c}\text { Yield stress can be specified Min 140MPa \& } \\
\text { Tensile Strength can be specified Min 270MPa }\end{array}$} \\
\hline
\end{tabular}

In the current scenario, a need was felt to study the air bending process experimentally for CR4 steel and to investigate the effects of process parameters like tool geometry, the orientation of sheet metal and punch speed on bending force and correlate the same with punch travel, because bend angle is adjusted by punch travel in industry. These results will be useful for design engineers and press shop engineers for deciding press specifications and tool strategy and tool setting in the fabrication industry.

\section{MATERIALS AND METHODS}

The material used in this study was 1mm thick CR4 steel sheet, for which chemical composition was analyzed by spark atomic emission spectrometry as per ASTM-E4152014 test method and results obtained were as per Table 3. The tensile test was 
conducted as per IS 1608:2005 considering the anisotropy. Tensile test samples were cut along rolling direction, transverse direction and at $45^{\circ}$ to the rolling direction. Results obtained are given in Table 4 . Results were as per specified limit.

Table 3. Chemical composition of CR4 steel

\begin{tabular}{|c|c|c|c|}
\hline Element & $\%$ & Element & $\%$ \\
\hline Carbon & 0.057 & Copper & $<0.01$ \\
\hline Manganese & 0.189 & Niobium & $<0.005$ \\
\hline Sulphur & 0.013 & Nitrogen & $<0.004$ \\
\hline Phosphorus & 0.018 & Boron & $<0.0005$ \\
\hline Aluminium & 0.043 & Lead & $<0.001$ \\
\hline Silicon & $<0.017$ & Cobalt & $<0.005$ \\
\hline Chromium & 0.018 & Vanadium & $<0.005$ \\
\hline Molybdenum & $<0.005$ & Tungsten & $<0.005$ \\
\hline Nickel & $<0.025$ & Iron (By Difference) & 99.61 \\
\hline
\end{tabular}

Table 4. Mechanical properties of CR4 steel

\begin{tabular}{|c|c|c|c|c|}
\hline Orientation & Yield stress & $\begin{array}{c}\text { Tensile } \\
\text { strength }\end{array}$ & $\begin{array}{c}\text { Elongation } \\
\text { Lo=50 }\end{array}$ & Hardness \\
\hline & $(\mathrm{M} \mathrm{Pa})$ & $(\mathrm{M} \mathrm{Pa})$ & $\%$ & HV5 \\
\hline $0^{\circ}$ & 181.2 & 318.7 & 45 & \\
\hline $90^{\circ}$ & 190.6 & 318.7 & 43.8 & \\
\hline $45^{\circ}$ & 193.4 & 335.5 & 37 & \\
\hline Average & 189.65 & 327.1 & 40.7 & \\
\hline \multicolumn{4}{|c|}{ Xaverage $=\mathrm{X} 0+2 \mathrm{X} 45+\mathrm{X} 90$} \\
\end{tabular}


Experiments were conducted on HT-U 1605- HS, twin column Universal Testing Machine. The machine was equipped with a $500 \mathrm{Kg}$ load cell and electrical servo control programmable drive to control speed and distance, having $1 \mathrm{~mm} / \mathrm{min}$ to $500 \mathrm{~mm} / \mathrm{min}$ variable cross head speed with computer interface for analysis and chart recording. Figure 3 shows the experimental setup.

(a)

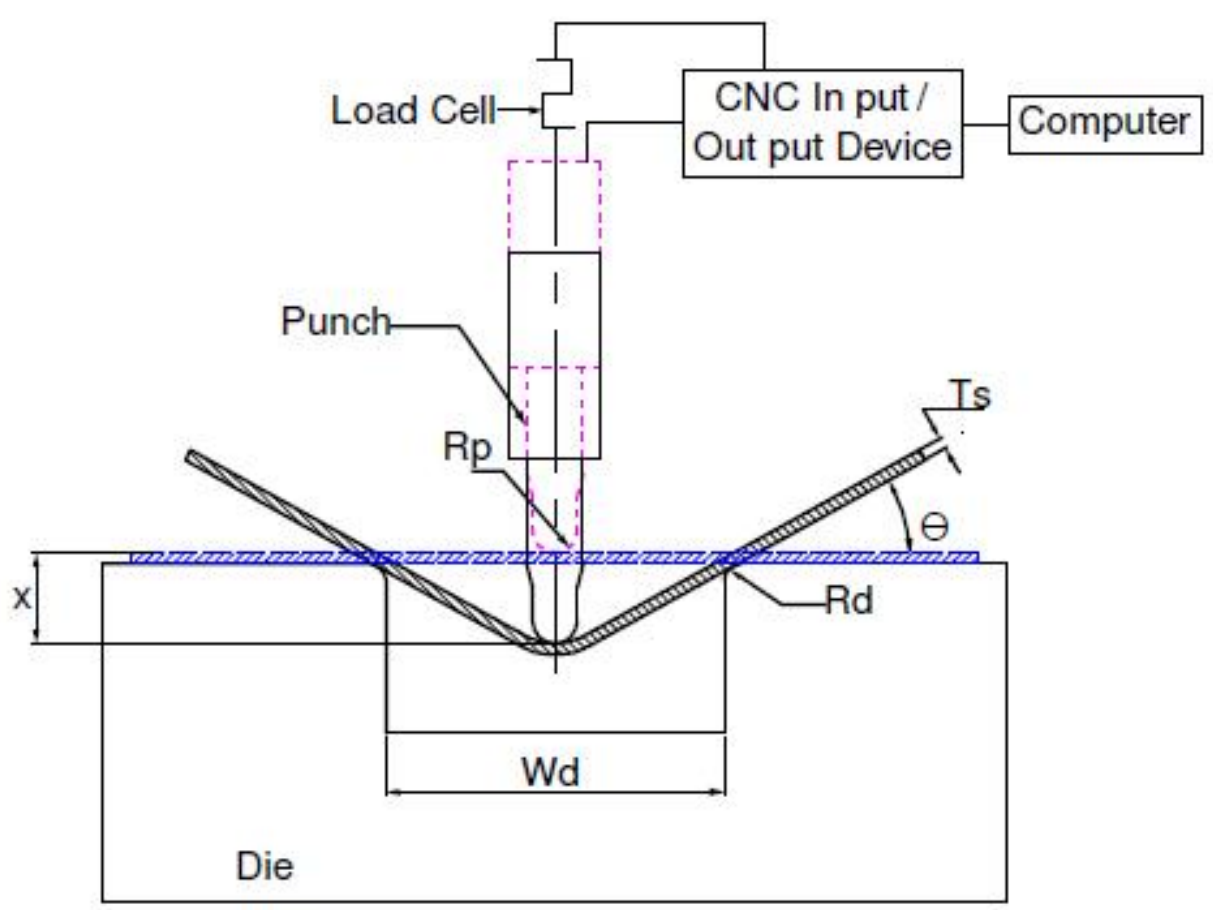

(b)

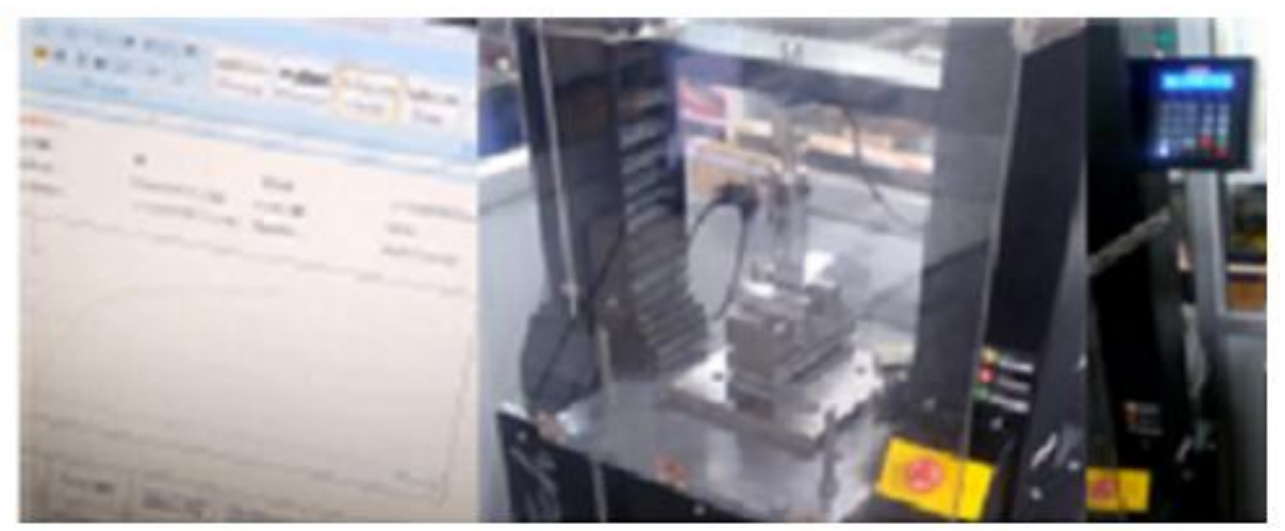

Figure 3. Experimental setup: (a) schematic diagram and (b) pictorial view

Various parameters used for experimentation for bending are given in Table 5. Rolling direction was considered $0^{\circ}$ and bending was done across of the rolling direction. Across rolling, transverse, direction was considered $90^{\circ}$ and bending was done in the 
rolling direction. Three punches with different radii and one flexible die set having different die radii and die widths were used. Three different punch speed with different punch travels were used to see the effect on bending force at different angles. Peak bending force $\&$ terminating bending force were recorded for each punch travel.

Table 5. Overview of tool parameters used in experiment

\begin{tabular}{|c|c|c|c|c|}
\hline \multicolumn{4}{|c|}{ Input parameters } & \multirow{2}{*}{$\begin{array}{c}\text { Response } \\
\text { Bending force y }(\mathrm{kgf})\end{array}$} \\
\hline \multirow[t]{3}{*}{ Constant } & Work blank width & Ws (mm) & 35 & \\
\hline & Work blank length & Ls (mm) & 150 & \\
\hline & Work blank thickness & Ts (mm) & 1 & \\
\hline \multirow[t]{6}{*}{ Variables } & Die width & $\mathrm{Wd}(\mathrm{mm})$ & $40, \mathbf{6 0}, 80$ & \\
\hline & Punch radius & $\mathrm{Rp}(\mathrm{mm}$ & $\mathbf{8}, 12,16$ & \\
\hline & Die radius & $\mathrm{Rd}(\mathrm{mm})$ & $3, \mathbf{5}, 8$ & \\
\hline & Punch travel & $\mathrm{x}(\mathrm{mm})$ & $5,10,15,20,25$ & \\
\hline & Orientation of sheet & $\left({ }^{\circ}\right)$ & $\mathbf{0}, 90$ & \\
\hline & Punch speed & $\mathrm{Vp}(\mathrm{mm} / \mathrm{sec})$ & $\mathbf{0 . 4}, 0.6,0.8$ & \\
\hline
\end{tabular}

\section{RESULTS AND DISCUSSION}

Effect of various parameters on bending force was plotted at various punch travel on the graph and illustrated.

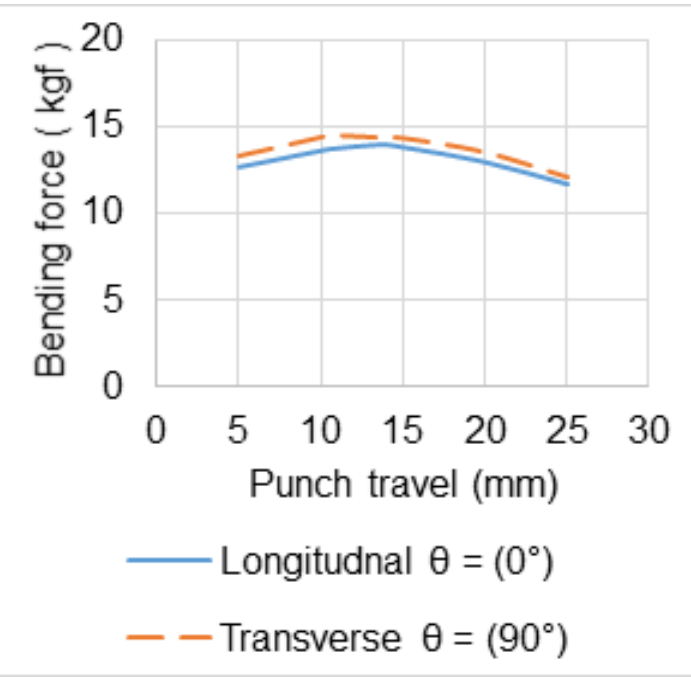

Figure 4. Effect of orientation

$(\mathrm{Rp}=8 \mathrm{~mm} ; \mathrm{Rd}=5 \mathrm{~mm} ; \mathrm{Wd}=60 \mathrm{~mm} ; \mathrm{Vp}=0.4 \mathrm{~mm} / \mathrm{sec})$ 
Figure 4 shows the bending force for CR 4 steel sheet for $0^{\circ}$ and $90^{\circ}$ orientations. It was observed that at $90^{\circ}$ orientation the bending force was more as compared to $0^{\circ}$ since ductility is reduced in transverse direction [6]. It was also observed with the increase of punch travel the bending force was increasing and after reaching maximum load on a further increase of punch travel bending force decreases in both $0^{\circ}$ and $90^{\circ}$ orientations. Reason being for larger punch travel, bending moment changes and deformation zone spread out producing a larger amount of friction work. The effect of bending moment and friction increases the bending force for a given punch travel. Punch travel for peak load has shifted indicating different strain behavior for both orientations. Naraynasamy, R. et al. observed the similar results for interstitial free steel sheets [3].

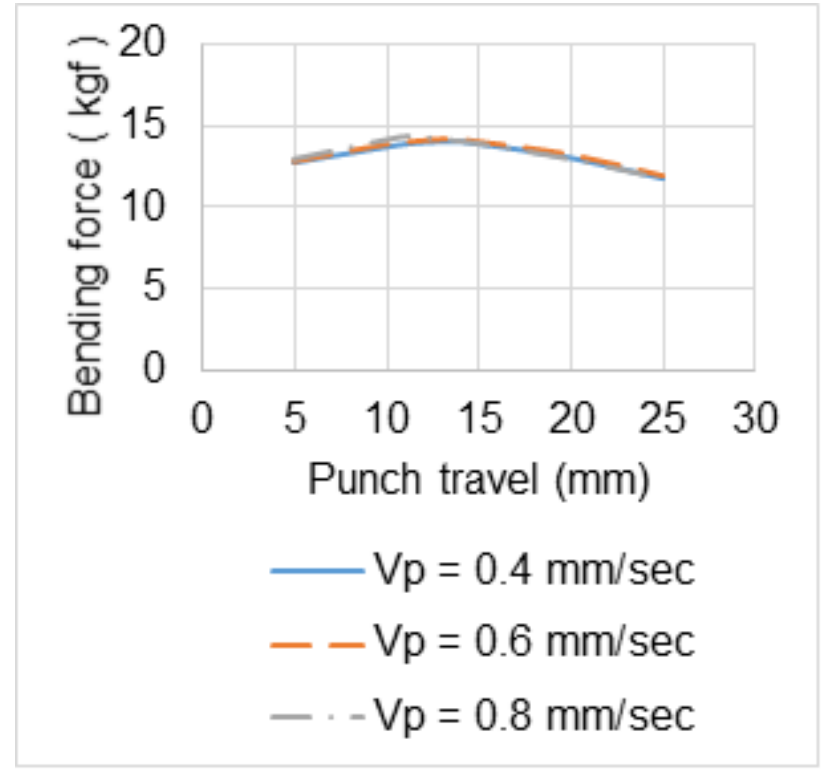

Figure 5. Effect of punch speed $\left(\mathrm{Rp}=8 \mathrm{~mm} ; \mathrm{Rd}=5 \mathrm{~mm} ; \mathrm{Wd}=60 \mathrm{~mm} ; \theta=0^{\circ}\right)$

Figure 5 shows the effect of punch speed on bending force. It was observed with the increase of punch speed bending force was increasing for each punch travel, till maximum load increases, after that it falls at a higher rate. It may be due to the positive strain rate sensitivity of CR4. The reason may be, the dynamic friction is more dominant than static friction and so the force of friction, a part of bending force, is higher for higher punch speed. The value of the coefficient of friction decreases with the increase of speed. The increase was more prominent at higher punch travel near peak load. Naraynasamy, R. et al. observed the similar results for interstitial free steel sheets [3] 


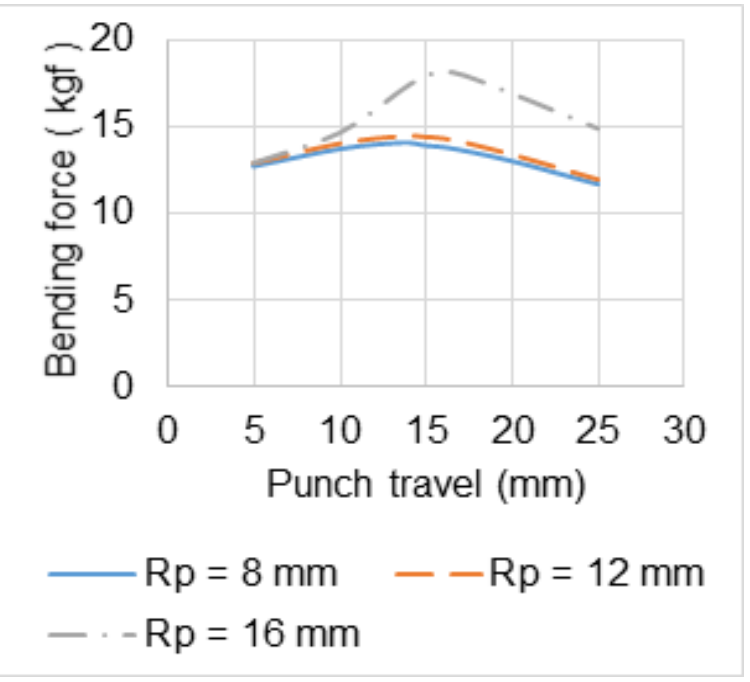

Figure 6. Effect of punch radius

$\left(\mathrm{Rd}=5 \mathrm{~mm} ; \mathrm{Wd}=60 \mathrm{~mm} ; \mathrm{Vp}=0.4 \mathrm{~mm} / \mathrm{sec} ; \theta=0^{\circ}\right)$

Figure 6 shows the effect of punch radius on bending force. It was observed with the increase of punch radius bending force was increased. Because on increase of punch radius, the contact area of punch increases. So, the free length between die and punch reduces and moment arm decreases, which leads to decrease of bending moment. It provides poor leverage so bending force increases. It is to be noted that the effect of punch radius was not significant on bend force for low ranges of punch travel since contact area of punch does not increase much. It was thus seen that the influence of punch radius becomes stronger only at larger punch travel. Similar results were obtained by Huang, Y. et al., Balaji, S. V. et al. and Srinivasan, R. et al. [11-13]

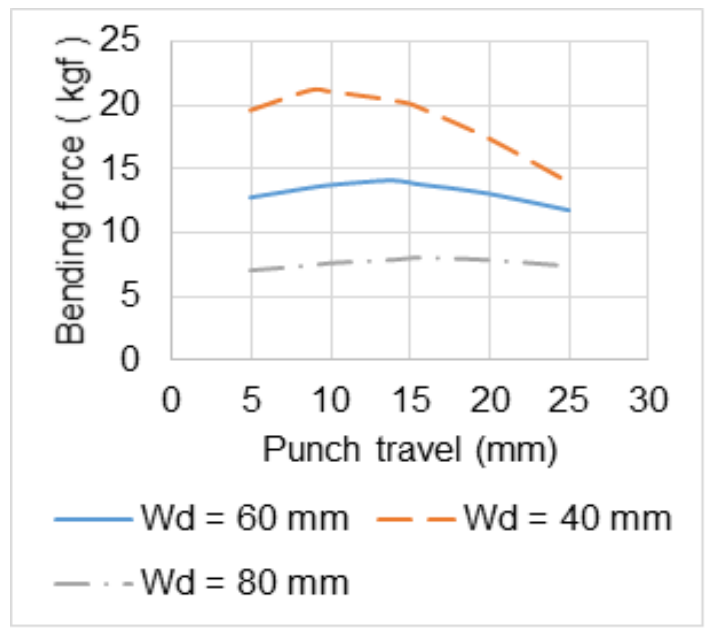

Figure 7. Effect of die width $\left(\mathrm{Rp}=8 \mathrm{~mm} ; \mathrm{Rd}=5 \mathrm{~mm} ; \mathrm{Vp}=0.4 \mathrm{~mm} / \mathrm{sec} ; \theta=0^{\circ}\right)$ 
Figure 7 shows the effect of die width on bending force. It was observed with the increase of die width bending force was decreased for each punch displacement. That was in conformation with the theoretical equation (1). Because on increase of die width free length between the punch and die increases, so moment arm increases, which leads to increase of bending moment, it provides better leverage so bending force decreases. Similar results were obtained by Srinivasan, R. et al. [13].

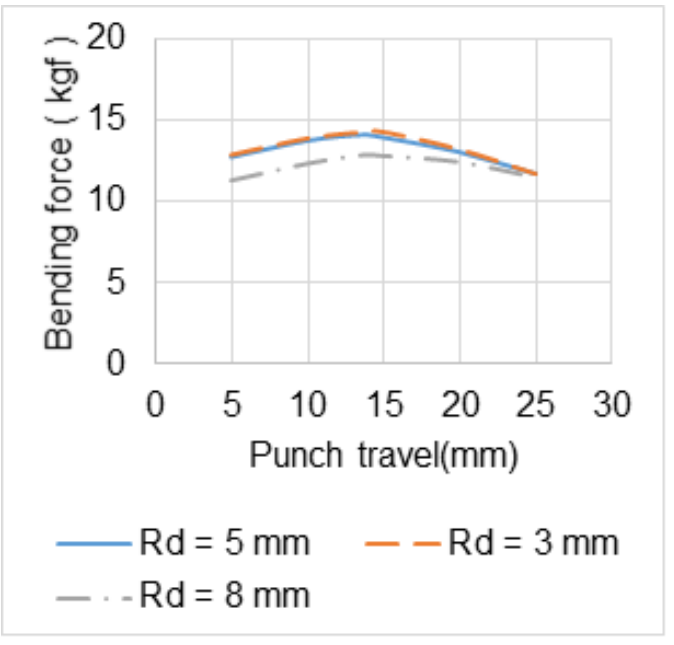

Figure 8. Effect of die radius

$\left(\mathrm{Rp}=8 \mathrm{~mm} ; \mathrm{Wd}=60 \mathrm{~mm} ; \mathrm{Vp}=0.4 \mathrm{~mm} / \mathrm{sec} ; \theta=0^{\circ}\right)$

Figure 8 shows the effect of die radius on bending force. It was observed with the increase of die radius, bending load get reduced. It was understandable, as happens in the case of die width. In this case, the point of contact between steel sheet and tool, that is, die and punch are spaced much apart, so moment arm increases which lead to the increase of bending moment. Thus, an increase of die radius decreases the bending force. The difference was increasing at higher punch travel near maximum load. Due to further punch travel, the difference was reducing.

Table 6. Correlation of punch travel and bending force

\begin{tabular}{|c|c|c|c|}
\hline Variable parameters & Type of curve & Equation & $\left(\mathrm{R}^{2}\right)$ \\
\hline $\begin{array}{c}\mathrm{Vp}=0.4 \mathrm{~mm} / \mathrm{sec} ; \\
\mathrm{Wd}=60 \mathrm{~mm} ; \\
\mathrm{Rd}=5 \mathrm{~mm} ; \\
\mathrm{R}=8 \mathrm{~mm} \\
\theta=0^{\circ}\end{array}$ & Exponential & $\mathrm{y}=14.239 \mathrm{e}^{-0.005 \mathrm{x}}$ & 0.2661 \\
\cline { 2 - 4 } & Linear & $\mathrm{y}=-0.0639 \mathrm{x}+14.18$ & 0.2541 \\
\cline { 2 - 4 } & Polynomial & $\mathrm{y}=-0.428 \ln (\mathrm{x})+14.363$ & 0.0708 \\
\cline { 2 - 4 } & Order: 2 & $\mathrm{y}=-0.0169 \mathrm{x}^{2}+0.4521 \mathrm{x}+10.911$ & 0.9881 \\
\hline
\end{tabular}




\begin{tabular}{|c|c|c|c|}
\hline Variable parameters & Type of curve & Equation & $\left(\mathrm{R}^{2}\right)$ \\
\hline & Order: 3 & $y=0.0002 x^{3}-0.0277 x^{2}+0.591 x+10.409$ & 0.992 \\
\hline & Order: 4 & $\begin{array}{c}\mathrm{y}=0.00008 \mathrm{x}^{4}-0.0045 \mathrm{x}^{3}+0.07034 \mathrm{x}^{2}- \\
0.2142 \mathrm{x}+12.555\end{array}$ & 0.9987 \\
\hline & Order: 5 & $\begin{aligned} y= & -0.00003 x^{5}+0.0023 x^{4}-0.0659 x^{3}+ \\
& 0.8788 x^{2}-5.1269 x+23.307\end{aligned}$ & 0.9999 \\
\hline & Power & $\mathrm{y}=14.481 \mathrm{x}^{-0.035}$ & 0.0781 \\
\hline
\end{tabular}

Table 6 shows various equations of trend line and their coefficient of determination, $\mathrm{R}^{2}$, computed using Microsoft Excel 2016 program for variable parameters, $\mathrm{Vp}=0.4$ $\mathrm{mm} / \mathrm{sec} ; \mathrm{Wd}=60 \mathrm{~mm} ; \mathrm{Rd}=5 \mathrm{~mm} ; \mathrm{Rp}=8 \mathrm{~mm}, \theta=0^{\circ}$. It was observed that polynomials are preferable among all equations and polynomial of a 2 nd order was the best fit since $\mathrm{R}^{2}$ is very close to 1 and for a higher order of the polynomial, the value was not increasing much and leads to inflexion. It was observed polynomial of a 2 nd order was fitting to all the tested combinations with $\mathrm{R}^{2}$ ranging from 0.8975 to 0.992 as shown in Table 7.

Table 7. Correlation of punch travel and bending force

\begin{tabular}{|c|c|c|c|}
\hline $\begin{array}{c}\text { Sl.N } \\
\text { o. }\end{array}$ & Experiment & Polynomial equation Order $: 2$ & $\left(\mathrm{R}^{2}\right)$ \\
\hline 1 & $\begin{array}{c}\mathrm{Vp}=0.4 \mathrm{~mm} / \mathrm{sec} ; \mathrm{Wd}=60 \mathrm{~mm} ; \\
\mathrm{Rd}=5 \mathrm{~mm} ; \mathrm{Rp}=8 \mathrm{~mm} ; \theta=0^{\circ}\end{array}$ & $\mathrm{y}=-0.0169 \mathrm{x}^{\mathbf{2}}+0.4521 \mathrm{x}+10.911$ & 0.9881 \\
\hline 2 & $\begin{array}{c}\mathrm{Vp}=0.4 \mathrm{~mm} / \mathrm{sec} ; \mathrm{Wd}=60 \mathrm{~mm} ; \\
\mathrm{Rd}=5 \mathrm{~mm} ; \mathrm{Rp}=8 \mathrm{~mm} ; \boldsymbol{\theta}=\mathbf{9 0}\end{array}$ & $\mathrm{y}=-0.0164 \mathrm{x}^{\mathbf{2}}+0.4240 \mathrm{x}+11.699$ & 0.9873 \\
\hline 3 & $\begin{array}{c}\mathbf{V} \mathbf{p}=\mathbf{0 . 6 m m} / \mathbf{s e c} ; \mathrm{Wd}=60 \mathrm{~mm} ; \\
\mathrm{Rd}=5 \mathrm{~mm} ; \mathrm{Rp}=8 \mathrm{~mm} ; \theta=0^{\circ}\end{array}$ & $\mathrm{y}=-0.0178 \mathrm{x}^{\mathbf{2}}+0.4815 \mathrm{x}+10.9$ & 0.9898 \\
\hline 4 & $\begin{array}{c}\mathbf{V} \mathbf{p}=\mathbf{0 . 8 m m} / \mathbf{s e c} ; \mathrm{Wd}=60 \mathrm{~mm} ; \\
\mathrm{Rd}=5 \mathrm{~mm} ; \mathrm{Rp}=8 \mathrm{~mm} ; \theta=0^{\circ}\end{array}$ & $\mathrm{y}=-0.0174 \mathrm{x}^{\mathbf{2}}+0.4428 \mathrm{x}+11.353$ & 0.9531 \\
\hline 5 & $\begin{array}{c}\mathrm{Vp}=0.4 \mathrm{~mm} / \mathrm{sec} ; \mathrm{Wd}=60 \mathrm{~mm} ; \\
\mathrm{Rd}=5 \mathrm{~mm} ; \mathbf{R p}=\mathbf{1 2 m m} ; \theta=0^{\circ}\end{array}$ & $\mathrm{y}=-0.0193 \mathrm{x}^{\mathbf{2}}+0.5294 \mathrm{x}+10.742$ & 0.9874 \\
\hline 6 & $\begin{array}{c}\mathrm{Vp}=0.4 \mathrm{~mm} / \mathrm{sec} ; \mathrm{Wd}=60 \mathrm{~mm} ; \\
\mathrm{Rd}=5 \mathrm{~mm} ; \mathbf{R p}=\mathbf{1 6 m m} ; \theta=0^{\circ}\end{array}$ & $\mathrm{y}=-0.037 \mathrm{x}^{\mathbf{2}}+1.2408 \mathrm{x}+7.2077$ & 0.8975 \\
\hline
\end{tabular}




\begin{tabular}{|c|c|c|c|}
\hline $\begin{array}{c}\text { Sl.N } \\
0 .\end{array}$ & Experiment & Polynomial equation Order $: 2$ & $\left(\mathrm{R}^{2}\right)$ \\
\hline 7 & $\begin{array}{c}\mathrm{Vp}=0.4 \mathrm{~mm} / \mathrm{sec} ; \mathbf{W d}=\mathbf{4 0 m m} \\
\mathrm{Rd}=5 \mathrm{~mm} ; \mathrm{Rp}=8 \mathrm{~mm} ; \theta=0^{\circ}\end{array}$ & $\mathrm{y}=-0.0327 \mathrm{x}^{2}+0.673 \mathrm{x}+17.46$ & 0.9876 \\
\hline 8 & $\begin{array}{c}\mathrm{Vp}=0.4 \mathrm{~mm} / \mathrm{sec} ; \mathbf{W d}=\mathbf{8 0 m m} ; \\
\mathrm{Rd}=5 \mathrm{~mm} ; \mathrm{Rp}=8 \mathrm{~mm} ; \theta=0^{\circ}\end{array}$ & $\mathrm{y}=-0.0075 \mathrm{x}^{2}+0.2454 \mathrm{x}+5.9817$ & 0.9684 \\
\hline 9 & $\begin{array}{c}\mathrm{Vp}=0.4 \mathrm{~mm} / \mathrm{sec} ; \mathrm{Wd}=60 \mathrm{~mm} ; \\
\mathbf{R d}=\mathbf{3 m m} ; \mathrm{Rp}=8 \mathrm{~mm} ; \theta=0^{\circ}\end{array}$ & $\mathrm{y}=-0.0186 \mathrm{x}^{2}+0.4987 \mathrm{x}+10.831$ & 0.9876 \\
\hline 10 & $\begin{array}{c}\mathrm{Vp}=0.4 \mathrm{~mm} / \mathrm{sec} ; \mathrm{Wd}=60 \mathrm{~mm} ; \\
\mathbf{R d}=\mathbf{8 m m} ; \mathrm{Rp}=8 \mathrm{~mm} ; \theta=0^{\circ}\end{array}$ & $\mathrm{y}=-0.0136 \mathrm{x}^{2}+0.4172 \mathrm{x}+9.5994$ & 0.992 \\
\hline
\end{tabular}

All equations are applicable for $5 \leq x \leq 25$, ( $\mathrm{x}=$ punch travel and $\mathrm{y}=$ bending force $)$, For bending ymax is required, once punch travel $\mathrm{x}$ crosses this force.

\section{CONCLUSION}

As per the results obtained from the experiments and discussion, it is concluded that

- Die width is the main source for reducing the bending force and by increasing die radius it can be further reduced marginally. These two parameters can be used to produce a part on a low capacity press.

- A decrease of punch radius decreases the bending force. Change of orientation of steel sheet and velocity has a marginal effect on bending force.

- Maximum bending force on the graph should be considered, since peak force shifts with the shift of one parameter to the other and not fixed for punch travel.

- Bending force follows polynomial equation of 2 nd order, so bending force chart can be tailor made after few trials for shop requirement.

\section{ACKNOWLEDGEMENTS}

Authors of this paper are highly thankful, for awarding and reinforcing this research work, to IKG Punjab Technical University, Kapurthala(Pb), India.

\section{REFERENCES}

[1] De Vin, L.J.,2000, “Curvature prediction in air bending of metal sheet." Journal of Materials Processing Technology, 100 (1-3), 257-261. DOI: 10.1016/S09240136(99)00489-6

[2] Kurtaran, H., 2008, "A novel approach for the prediction of bend allowance in air bending and comparison with other methods." International Journal of Advanced Manufacturing Technology, 37(5-6), 486-495. DOI: 10.1007/s00170 -007-0987-y 
[3] Narayanasamy, R., and Padmanabhan, P., 2009, "Application of response surface methodology for predicting bend force during air bending process in interstitial free steel sheet." International Journal of Advanced Manufacturing Technology, 44(1-2), 38-48. DOI: 10.1007/s00170-008-1811-z

[4] Garcia-Romeu, M. L., Ciurana, J. and Ferrer, I., 2007 "Spring back determination of sheet metals in air bending process based on an experimental work." Journal of Materials Processing Technology, 191(1-3), 174-177. DOI: 10.1016/ j.jmatprotec. 2007.03.019

[5] De Vin, L.J., 2001, "Expected the unexpected, a must for accurate brake forming." Journal of Materials Processing Technology, 117(1-2), 244-248. DOI:10.1016/S0924-0136(01)01140-2

[6] Kalpakjian, S, and Schmid, S. R., 2013, Manufacturing Processes for Engineering Materials. Fifth Edition; Pearson, Publisher: Dorling Kindersley (India), New Delhi., pp. 94-95; 366-367,

[7] Boljanovic, Vukota., 2004, Sheet metal forming process and die design, Industrial Press Inc. New York, pp. 53,

[8] Farsi, M. A., and Arezoo, B., 2011, "Bending force and spring -back in V-die bending of perforated sheet metal components." Journal of the Brazilian Society of Mechanical Science and Engineering, XXXIII (1).45-51

[9] Carden, W. D., Geng, L. M., Matlock, D. K., and Wagoner., 2002, "Measurement of spring back." International Journal of Mechanical Science, 44(1), 79-101. DOI: 10.1016/S0020-7403(01)00082-0.

[10] Marciniak, Z., Duncan, J. L., and Hu, S. J.,2002, Mechanics of sheet metal forming, Second edition, Butterworth-Heinemann, Linacre House, Jordan Hill, Oxford, pp. 90.

[11] Huang, Y., and Leu, D.K.,1998, "Effects of process variables on V-die bending process of steel sheet - part I-theory." International Journal of Mechanical Sciences, 40(7), 631-650. DOI: 10.1016/0020-7403(97)00083-0

[12] Balaji, S.V., Karuppuswamy, P., and Karuppusamy, S.,2014, "Experimental analysis of ' $\mathrm{V}$ ' die air bending of $\mathrm{Fe} 410 \mathrm{~W}-\mathrm{C}$ steel plate." International Journal of Current Engineering and Technology, E-ISSN 2277- 4106, P-ISSN 2347 5161 @2014 INPRESSCO®, 194-199. DOI: 10.14741/ijcet/spl.2.2014.35

[13] Srinivasan, R., Vasudevan, D., and "Palani, P., 2012, "Experimental investigations of bend force in air bending of electro galvanised steel sheets." Journal of Materials Engineering and Performance, 21(7), 1188-92. DOI: 10.1007/s11665-011-0029-7

[14] Chatti, S., Weinrich, A., Budamusi, M. El. Becker C., Maevus, F., and Tekkaya A. E., 2015, "Influencing the forming limits in air bending using incremental stress superposition.” Key Engineering Materials, 651-653, 1602-1607. DOI: 10.4028/www.scientific.net / KEM.651-653.1602

[15] Khalatbari, H., Iqbal, A., Shi, X., Gao, L., Hussain, G., and Hashemipour, M., 2015, "High speed incremental forming process: a trade-off between formability and time efficiency." Materials and Manufacturing Processes, 30(11) DOI: 10.1080/10426914.2015.1037892 
[16] Gupta, Tilak Raj, and Payal, H. S., 2016 "Investigative study on bending and spring back of electro galvanised steel." Proceedings of the 5th International Symposium on "Fusion of Science \& Technology", New Delhi, India, January 18-22, 461-465. ISBN: 978-93-84935-64-1, pp. 461-465

[17] Khadra, F. A., and El-Morsy, A.W., 2016, "Prediction of spring back in the air bending process using a kriging metamodel." Engineering, Technology \& Applied Science Research, 6(5), 1200-1206. ISSN 1792-8036.

[18] Salahshoor, M; Gorji, A.; Jooybari, M. B., 2016, "Analysis of the effects of tool and process parameters in hydroforming process." Proceedings of the 4th International Conference on Electrical, Computer, Mechanical and Mechatronics Engineering (ICE2016), Dubai, Emirates. February,4-5, pp

[19] IS 513:2008, Indian Standard, Cold Reduced Low Carbon Steel Sheet and Strip, Fifth Revision, (Amendment No. 1 July 2010) Bureau of Indian Standards. ICS 77.140 .50

[20] Suresh, K., Bagade, S. D., and Regalla, S. P., 2015 "Deformation behaviour of extra deep drawing steel in single point incremental forming." Materials and Manufacturing Processes, 30(10)1202-1209 